\title{
Management Succession and Entrepreneurship Business Sustenance
}

\author{
Solomon A. Kowo1@四, Olalekan O. Akinrinola ${ }^{2}$, \\ Olufemi A. Akinbola ${ }^{3}$ D \\ ${ }^{1}$ Kwara State University, \\ $P M B-1530$, Ilorin, Kwara State, Nigeria \\ ${ }^{2}$ Caleb University, \\ PMB - 1, Imota, Lagos State, Nigeria \\ ${ }^{3}$ Federal University of Agriculture, \\ PMB - 2240, Alabata road, Abeokuta, Ogun State, Nigeria \\ \kowosolomon@gmail.com
}

\begin{abstract}
Succession planning has drawn substantial interest among researchers. Research reports designate deficiency of quality planning in the management of SMEs especially in developing countries like Nigeria and this constitutes a foremost limitation to the effective management of SMEs. Succession planning are fundamental to steady performance, sustainability and competitive advantage of SMEs. The objective of the study was to investigate the effects of HR planning/forecasting on family business continuity and also to examine the effect of worker's education on survival of entrepreneur. 110 copies of questionnaire were administered to the employees in the five selected SMEs in Abeokuta Ogun state, Nigeria to get primary data that treated and tested appropriate research questions and hypotheses accordingly. Analysis of variance (ANOVA), correlation efficient and regression analysis was employed. The Yamane formula was used to determine the sample size. The test re-test reliability approach was adopted for the convenience of the researcher. Reliability was ensued by Cronbach's Alpha of 0.932 . The data was analyzed using manual and electronic based methods through the data preparation grid and statistical package for the social sciences, (SPSS). The study found out that HR succession planning significantly assists SMEs to increase business continuity and Workers education significantly assists SMEs to increase business survival. The study recommends that organizational succession planning should be at regular interval as this will enable workers to know its importance and also business successors should be appointed based on merit so that the right and experience successors can manage the business.
\end{abstract}

Keywords: management succession, business sustenance, worker's education, HR planning, business continuity

Conflicts of interest: The authors declared no conflicts of interest.

Article history:

The article was submitted on 01.05.2021. The article was accepted on 31.05.2021.

(C) Kowo S.A., Akinrinola O.O., Akinbola O.A., 2021

This work is licensed under a Creative Commons Attribution 4.0 International License https://creativecommons.org/licenses/by/4.0/ 
For citation:

Kowo S.A., Akinrinola O.O., Akinbola O.A. Management Succession and Entrepreneurship Business Sustenance. RUDN Journal of Public Administration. 2021;8(3):256-276. DOI: 10.22363/ 2312-8313-2021-8-3-256-276

\section{Introduction}

Management succession has been in existence as far back as the early twenty first century with Henry Fayol's 14 principles of management published in 1916. When the owner/founder of a business is getting old or is no more pro-active as before, there will be need to look for someone who is competent and trust worthy to carry on the business. The process of searching for a competent successor to take over the business is referred to as succession planning. Over time, family business has grown to become one of the major concern agenda in the global entrepreneurial development. Entrepreneurship business is an emerging field which has evolved over the decades and still in its developing stage. Today, most of the businesses we see are family businesses and these businesses have been noted to account for the largest percentage of the businesses in many nations including Nigeria [1]. The importance of family business cannot be undermined. They are visible in the employment generation, economic growth and transformation and wealth creation. This is an awesome contribution and is expected to happen to most countries in the world considering the contribution and development of small firms in the recent years [2]. Fayol was to introduce management succession and he posited that if management succession needs were ignored, small business owners would not be prepared to make necessary transitions [3].Management succession embraces not only identifying qualified and motivated candidates for promotion but also developing their capabilities in a manner that will prepare them to perform effectively in leadership positions [4]. Coaching and mentoring have become widely accepted techniques for extending such development beyond classroom training and on-the-job experience. These strategies are only effective to the extent that they include structured activities conducted to achieve targeted goals by those with training to properly facilitate the process. Succession planning process includes three main components. As human societies have moved to industrialization from being traditional and then to post-industrialization, sciences and technology are also transformed and developed. Due to these changes, importance of education necessity and features are indicated more than before. Some scholars state about importance of education: "actually, education is management" which means that without staff education, management basics will be insecure and in danger. Staff education is vital and inevitable which should be continuously noticed with management procedures; so that, other management activities will be useful. In fact, education is one of the fundamental and logical ways for guidance of staff attempts in organization and it causes utilization of latent talents, imagination power and creation of intellectual flexibility in staff. Nowadays, organizations need a group of high potential people at all levels of their organizations. Developing general competencies, creating flexibility and creating the leadership potential at all organizational levels are a wise action in today's organizations $[5 ; 6]$. 


\section{Statement of Research Problem}

Organizations nowadays are looking forward to have a competitive advantage against the threats in globalization. Due to the high competency requirements most organization aims to generate the kind of performance that can bring more profit. In order to do that the employers are required to provide for proper HR planning/forecasting, as poor HR planning/forecasting could affect business continuity. Human resource planning involves identifying staffing needs, forecasting available personnel, and determining what additions or replacements are required to business continuity in order to achieve the organization's goals [7]. This is made worse if the manager does not possess requisite qualifications. Many organizations in Nigeria do not give it the pride of place as they consider much on the cost implications involved and the rate at which workers do leave/resign for another employment. In fact, this issue of just resigning for another employment after much has been expanded on employee for training has become so rampant that organizations do have a second thought on training and development of employees[8]. Today's environments are changing rapidly that organizations are facing serious unpredictability and uncertainty which sometimes causes instability in the business operations. In this unstable environment organizations need to rely on the most important assets: their people [9].

\section{Literature Review}

\section{Concept of Succession Planning}

Succession planning refers to the process of identifying employees who have the potential to assume key positions in the organization and preparing them for these positions [10]. Noe, et al, [11] define succession planning as a process of identifying and preparing suitable high potential employees to replace key players within the organization as their terms expire. Sambrook [4] defined succession planning as "the attempt to plan for the right number and quality of managers and key-skilled employees to cover retirement, death, serious illness or promotion, and any new positions which may be created in future organization plans". The availability of the right number, right management staff at the right time and in the right positions is imperative. A sudden vacancy can lead to confusion and loss of efficiency as the search for a replacement is conducted. The absence or loss of an employee could cause an inconvenience that could be avoided with some anticipation to serious succession development [12;13]. Therefore, planning on how one's shoe is going to be filled when he is no longer there and even planning for knowledge coverage when one is ill or vacationing simply makes good business sense. For professionally run corporations, the single most important reason for having a sound succession plan is usually better retention because of growth opportunities and job satisfaction among employees. Therefore, for a company that wishes to enhance its performance, to allow its high potential employees turnover is not an option but to rather arrange them in systematic successions, by enabling them to effectively perform roles traditionally reserved for managers [4]. It also helps employees prepare for changes in their current jobs that may result from new 
technology, work designs or new product markets. Thus, succession planning is a necessary component of a company's effort to improve quality, meet challenges of global competition, social change and incorporate technology advances. Ruthwell [14] examined succession planning as a staffing responsibility that relates to promotions, terminations and retirement. In addition, succession planning has a direct impact on reducing staff turnover. Succession planning is a deliberate and systematic effort by an organization to ensure leadership continuity in key positions, retain and develop intellectual and knowledge capital for the future and encourage individual advancement [15]. Succession planning can also be defined as a process which ensures the continued effective performance of an organization by establishing a process to develop and replace key staff over time [16].George et al, [13] posit that succession planning is perpetuating the enterprise by filling the pipeline with high-performing people to assure that every leadership level has an abundance of these performers to draw from both now and in the future. From this perspective, succession planning is seen as management pipeline that accelerates management performance over a period of time. George' definition looks into the future and this probably influences Sambrook [4] assertion that succession planning is co-creating a transformational stage during which management explores the future. Succession planning is organized process comprising the identification and preparation of potential successor to assume new role [17; 18]. However, this definition is short and compact but it is not futuristic and lack strength when compared with George definition.

Leubsdorf [19] identifies three types of planning that aim at achieving practical goals and objectives of organization.

- Micro-planning deals with forecasting supply and demand for specific groups.

- Contingency planning covers the situation where possible scenarios are examined and the implications assessed before major decisions are taken.

- The third type focuses on manpower planning activity such as recruitment and development of employees in order to fill managerial and top positions. Succession planning is a process that can provide seamless leadership transition across the organization". Strategic, systematic and deliberate effort to develop competencies in potential leaders through proposed learning experiences such as targeted rotations and educational training in order to fill high-level positions without favoritism [20;21]. In this context succession planning encompasses not only top management but also a number of other factors. It can cover issues such as the procedures necessary for a successful transfer, legal and financial considerations, psychological factors, leadership development, and exit strategies $[22 ; 23]$.

The talent management approach to succession planning is one that is deliberate, future oriented, and based on developing competencies of multiple individuals rather than a single individual. These models include a thoughtful strategy for managing an organization's total human capital and their total workforce $[2 ; 24]$.This latest evolution of succession planning models has been influenced by external social, political, economic and technological changes in our society and by internal expectations of organizations and employees. The next 
section of literature review examines these types of external and internal influences on the evolution of succession planning.

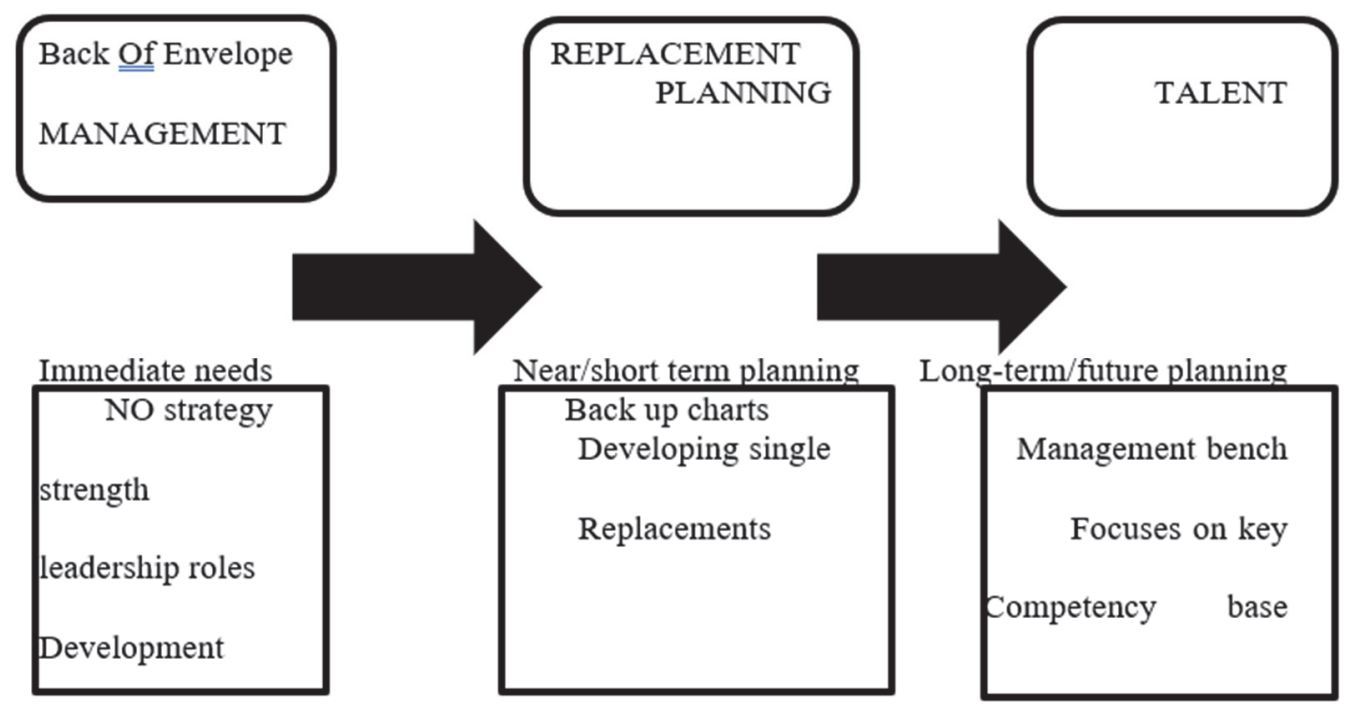

Fig. 1. Succession planning model Source: [9]

\section{External Influences on Succession Planning}

When Henri Fayol developed his fourteen points of management that prompted early models of succession planning in 1916, the societal, political and economic climate was quite different than it is today [9]. The following pages examine these external influences on succession planning with specific attention on six influences which include:

1. social changes.

2. Technological advancements.

3. Economic conditions.

4. Political environments.

5. The increase of knowledge and information.

6. The changing demographics and workforce.

Social Changes. George [13] describe the period between 1900-1920, as a significant time in US history; a time that marked significant evolution in business, industries, and even technology. During this period in American history, our society evolved from one that was predominantly agrarian and focused on farming to an industrial society where factory work and manufacturing industries influenced business and organizations [25]. In these early days of the century, it was assumed that one would walk into the footsteps of one's father or grandfather as in previous generations. Consequently, planning for replacements did not require as much strategy as it would in future decades. The advent of new technology in the form of automobiles, gasoline, and new farming equipment allowed individuals the flexibility to move away from family farms and seek other business opportunities which many of them did $[10 ; 24]$. Society was changing and farmers and business owners began to realize the importance of strong leadership. Other influences 
included advances in technology, changing economic and political climates, and a notable shift in the workplace demographics.

Technological Advances. Perhaps the best way to sum up the differences in technology from the 1900s till today can be found in Collins \& Lazier [20] statement that "just as the automobile shaped society in the $20^{\text {th }}$ century, the Internet is shaping society in the 21 stcentury". Technology is persistent in virtually every facet of American business and drives many of the business and productivity decisions made by organizations, including decisions around leadership development and succession planning. Technology affects more than bottom-line business and also technology impacts the overall economy, and how we prepare young people for the workforce [26; 27]. Fulmer [24] pointed that "the Internet has enhanced the mobility of leadership talent, making it easy for employees to find opportunities elsewhere". The impact of technology on succession planning can be seen in the evolving complexity of models. No longer is it sufficient to develop a single individual to take a leadership post in a company. Today, companies know they must provide leadership development opportunities as a way of attracting and retaining talented workers who have many more options than they did in the 1900s [24; 28].

Economic Conditions. The years between 1950 and the dawn of the new century supported the continued emergence of industries outside farming. Maxwell [26] illustrate the dramatic increase in these new industries such as computers, health, and service sectors which grew from 45 million workers to over 129 million workers. By the 1980-1990s, the labor force had evolved well beyond the strong agricultural economy to a complex, global, and interdependent economy and organizations began to view the recruitment and development of leaders and talent as a way to remain responsive to market competition and improve business profitability [3]. Early in the twentieth century, the US economy was at a high, having come out of a recession earlier in the decade [29]. The previously strong economy had allowed businesses to divert their focus away from developing replacements for key leaders. But the economy would not stay for long as evidenced by the Great Depression from 1929-1940 [18]. These two decades would remind American businesses that organizations simply could not sustain themselves with a single great leader because no company was immune to external forces. As the economy and the number of qualified workers began to change, businesses and organizations started to rethink employee development needs and allocate more time and money to training employees [11].This investment in employee development was short lived as the trend began to reverse by the 1970s when the economy shifted once more. Organizations began to drastically reduce HR budgets for talent development and once again, the direct replacement approach became a cost effective alternative to developing multiple leaders. Today's leadership experts have made the case for the connection between strong leadership and long-term business productivity $[30 ; 31]$. Similarly, experts in succession planning have joined in building the business case for building a deep bench of leadership strength as a key indicator in business sustainability $[24 ; 16]$. This has resulted in a wealth of literature linking employee development to business profitability [17;28], which has again prompted organizations to consider strategic, deliberate succession plans that involve the commitment of many individuals in the organization. 
Political Environment. During a time when employee options were limited and companies experienced high levels of loyalty and longevity from their employees, the direct replacement method was common place. Just as the society and the economy influenced the way employees were selected to resume key positions, so too did the political environment. Before the Civil Rights Act of 1964, it was politically acceptable to appoint an individual to a leadership post without opening it for diverse applicants to apply. After that time, Title VII of the Civil Rights Act of 1964 prohibited "employment discrimination based on race, color, religion, sex, or national origin" making it more difficult to simply appoint a single direct successor without opening the process to other potentially qualified applicants [32; 33]. Today, the EEOC oversees employer compliance with federal regulations and many companies have developed sophisticated legal departments and employee relations staff to assist with succession planning efforts. This ensures that the hiring and selection process does not subject the organization to unnecessary legal scrutiny. This simple change in the political environment has become a catalyst for many organizations to begin considering broader pools of talent and move away from potentially political hotbeds of direct replacements in succession planning.

Changing Demographics and Workforce. The changing demographics around the globe will inevitably change the future available workforce. The U.S. economy once driven by 78.2 million baby boomers (born between 1946-1964) who "fueled the labor force for decades" is about to change as impending retirements will create a "sizable hole in the labor market" [19]. With more than 77 million baby boomers becoming retirement eligible in the coming decade, some experts predict the U.S. workforce will be short by as many as 10 million workers [28]. Rothwell [9] confirms this dramatic tightening on the labor force suggesting that already" 1 in 5 of all senior executives in the Fortune 500 and about $50 \%$ of the entire US government workforce is eligible to retire" now. Like their counterparts in business, educational institutions will also face challenges of replacing key leadership in the coming years as documented by many who have raised concern for academic leadership continuity $[30 ; 19]$ While the aforementioned external influences certainly have played a role in the evolution away from succession planning based on direct replacement to talent pools, it is this limited availability of the workforce that is probably the most significant influence on today's renewed interest in true succession planning. Whereas in 1982, only $38 \%$ of a company's value was attributed to "intangible assets" such as personnel, this would change by the turn of the century when the figure would rise to $80 \%$ as companies began focusing on attracting and developing quality employees as a key business strategy.

\section{Internal Influences on Succession Planning}

The shortage of skilled workers is of concern to businesses, that today's corporate human resources offices are now charged with developing new strategies to attract, recruit and retain a broader and deeper bench of leadership prospects [14; 28]. Today's HR professionals operate at the intersection of the external demographic shifts and internal organizational priorities that are designed to give the organization a competitive advantage into the future $[34 ; 15]$. 
Organizational Priorities. The Bureau of National Affairs indicated a dramatic increase in the recruitment and hiring function of HR departments between the years 1990-2000 when companies began to view employees as a valuable component of their competitive strategy [24]. The desire for sustained success has business executives thinking about succession planning as a top priority. In fact some of the most successful companies showcased in built to last were at the forefront of their industries for at least fifty years because of one common thread; they had a history of succession and leadership planning [20]. Today's organizational leaders recognize that it is wiser to focus beyond replacement planning to succession planning to build the long-term sustainability and viability of the organization [9]. This is in large part, due to the awareness of the connection between succession planning and the business bottom line.

Employee Expectations. Not only have employers noted the value of succession planning as a viable strategy for business prosperity, employees themselves have come to expect development opportunities from employers, making the presence of formal leadership programs a necessity for organizations to remain competitive in an environment with limited talent. Many organizations have begun to place increasing focus on learning and development; however, succession planning remains largely elusive in most colleges and universities [30; 31]. While the origins of succession planning efforts date back to the early $1900 \mathrm{~s}$, the evolution of our society, economy, technology and workforce has impacted how these plans are constructed and implemented in today's organizations. The evolution to a comprehensive talent management approaches offers opportunities for employees to develop personal leadership competencies while the organization simultaneously benefits from an overall increase in talent. The result is that organizations now see great value in developing their employees into leaders who will sustain the organization's mission while avoiding risks associated with a presumed single successor. Planning:

Vikstrom \& Westerberg [21] highlighted thirteen reasons for Succession

1. Provide opportunities for high-potential workers.

2. Identify replacement needs

3. Increase the talent pool of promotable employees

4. Contribute to implementing the organization's strategic business plans

5. Help individuals realize their career plans

6. Tap the potential for intellectual capital

7. Encourage the advancement of diverse groups

8. Improve employees' ability to respond to changing environmental demands

9. Improve employee morale

10. Cope with the effects of voluntary separation programs

11. Decide which workers can be terminated

12. Cope with the effects of downsizing

13. Reduce headcount to essential workers only

\section{Best Practices of Succession Planning [1]}

Armstrong believes an integrated talent management system will succeed if the organization faithfully adheres to certain practices. These practices include making long-range plans, conducting regular progress checks, connecting 
business strategies to needed competencies, developing a talent mindset among company leadership and integrating all talent-related initiatives. Let's look at each one in detail.

Long-range plans: The talent management planning process begins with the setting of long-range, achievable goals. What competencies will the company need in one to two years, or in three to five years? In the case of executive development, a plan may be laid out for the next 15 years. Jeff Oberlin, President of Jeff Oberlin, Inc. in Elmhurst, Illinois, is a business improvement executive who specializes in enterprise learning and work force productivity. He emphasizes that from line employees all the way up to CEO, companies need to make sure that they have a long-range view of where they are going, what type of talent they will need, the competencies required in particular jobs and across the board, and also the number of employees needed with certain skill sets. "Many times we forget to count the noses that are going to be required within an organization," Oberlin says, "and quantities definitely have to be taken into consideration as you start developing or acquiring certain types of talent." Recently, Chevron has experienced such growth that the company now focuses on forecasting future demand five to ten years out. Shawstad says she and other members of senior management look at supply, identify gaps and then develop plans to address those gaps. One such plan is a formal training program called Horizon, which focuses on making sure employees have the technical skills they need for the next five years.

Progress checks: Once an organization devises a strategic plan that impacts the acquisition and development of talent, it should conduct annual progress checks with quarterly reviews. Such reviews assess changing strategies and explore emerging marketplace threats and opportunities, which could necessitate adjustments to the plan. According to Oberlin, companies often build competency models and never revisit them. This reduces their effectiveness over time.

Connecting business strategies to needed competencies: Attention should be focused in the right direction in the talent management planning process. This means making the connections between business strategies and the competencies needed to implement them. Personnel in what would be called key, critical or pivotal positions in implementation projects can immensely influence the success or failure of strategic plans. For example, a company's business plan might call for a new initiative such as reducing long sales cycles, conducting Six Sigma quality improvement program or making a commitment to solving environmental issues. Whatever the initiative, change can only happen if the company has the right competencies in place. If it does not, the options are to hire new talent, develop existing talent or transfer personnel internally. Oberlin believes that implementation of strategy is a facilitative process. "It doesn't happen magically, or in a black box or in the software. It has to be teased out with the right kind of functional participants or leaders," he says.

Developing a talent mindset: Leadership throughout the organization needs to have a talent mindset that drives them to actively participate in the acquisition and development of talent. Because company culture is the soul of an organization, top executives need to help create and sustain a purposeful, engaging, rewarding and high performance work life. This requires constant attention and should be part of the annual talent planning process. 


\section{Theoretical Framework of Succession Planning}

Systems Theory. Systems theory was founded by Bertalanffy. The systems theory has had a significant effect on management science and understanding organizations [17]. A system is a collection of part unified to accomplish an overall goal. If one part of the system is removed the nature of the system is changed as well. A system can be looked at as having inputs (e.g., resources such as raw materials, money, technologies, and people), processes (e.g., planning, organizing, motivating, and controlling), outputs (products or services) and outcomes (e.g., enhanced quality of life or productivity for customers/clients, productivity). Systems share feedback among each of these four aspects of the system.

Contingency Theory. Contingency theory was developed by Fred Fiedler in the late 1960s. He believes the effectiveness of leadership styles vary depending on the situation. Contingency theory asserts that when managers make a decision, they must take into account all aspects of the current situation and act on those aspects that are key to the situation at hand. Basically, it is the approach that "it depends". For example, if one is leading troops against book haram, an autocratic style is probably best. If one is leading a hospital or University, a more participative and facilitative leadership style is probably the best.

Resource-Based Theories. The resource-based view (RBV) is a business management tool used to determine the strategic resources available to a company. The fundamental principle of the RBV is that the basis for a competitive advantage of a firm lies primarily in the application of the bundle of valuable resources at the firm's disposal (The resource-based view (RBV) is a business management tool used to determine the strategic resources available to a company. The fundamental principle of the RBV is that the basis for a competitive advantage of a firm lies primarily in the application of the bundle of valuable resources at the firm's disposal [7]. To transform a short-run competitive advantage into a sustained competitive advantage requires that these resources are heterogeneous in nature and not perfectly mobile [35]. Effectively, this translates into valuable resources that are neither perfectly imitable nor substitutable without great effort [25]. If these conditions hold, the firm's bundle of resources can assist the firm sustaining above average returns. The VRIO model also constitutes a part of RBV [19]. To transform a short-run competitive advantage into a sustained competitive advantage requires that these resources are heterogeneous in nature and not perfectly mobile [36]. Effectively, this translates into valuable resources that are neither perfectly imitable nor substitutable without great effort [36]. If these conditions hold, the firm's bundle of resources can assist the firm sustaining above average returns. The VRIO model also constitutes a part of RBV.

\section{Empirical Review}

Farashah et al [29] researched on succession planning and its effects on employee career attitudes using a case of Iranian governmental organizations. Their work evaluated effects of succession planning as an organizational level intervening program on career attitudes as individual level variables. Best practices of succession planning were selected from literature and compliance of succession 
planning system of organization to these practices was defined as extensiveness of succession planning. A 22-item questionnaire was developed to measure the extensiveness of succession planning. Validity and reliability of questionnaire were confirmed by appropriate tests. For career attitudes, 3 variables of promotion satisfaction, perception of career success, and perception of job platitude selected. Then the correlation of the succession planning extensiveness and three career attitudes were examined by empirical data gathered from 152 managers and key personnel in 23 large Iranian governmental organizations. They found that significant correlation existed between succession planning extensiveness and career success and satisfaction of promotion process. Perception of job did not show correlation with succession planning extensiveness. This study recognized best practices that should be considered for design of succession planning. Also the scale for measuring succession planning extensiveness developed. It can be used to gain a better understanding of status quo of succession planning in organizations and gap analysis which is generally one of the early stages of every organizational development project. George [13] reviewed succession planning in Iranian governmental agencies. They found that it was becoming increasingly challenging for organizations to obtain qualified and talented staff. Succession planning was often introduced as a way to attract and employ such staff. Succession planning is a process of recruitment and development of employees for vital roles within the organization. Implementation of succession planning was a central to certain organizational requirements. Armstrong [1] wrote a paper on competency-based succession planning: a strategic approach to addressing human capital challenges. $\mathrm{He}$ argues that for the past three decades, the concept of competency-based management has received ever increasing attention in the business management literature. This attention assumed crucial proportions as the industrial base of many countries is supplanted by the "knowledge economy," "information age," or "postindustrial society." As the knowledge economy grows, intellectual capital becomes the key differentiating factor for organizations. They found that to assure success, organizations must find ways of identifying, quantifying, measuring, assessing, and enhancing their intellectual capital assets. One way of accomplishing this oftentimes difficult task was through competency-based management. Fullmer [24] found that Succession planning is one small piece of the entire workforce planning strategy. Likewise, succession planning often works hand in hand with knowledge transfer concepts, since developing new leaders means that the knowledge of current leaders will be shared before retirement, promotion, or other attrition with those who will follow in their footsteps. As managers and supervisors develop and implement their workforce plans, it is helpful to see how different components all work together. As a piece of the workforce plan, succession planning has many benefits for both the current leadership and for the employees in the agency. Diamond [8] wrote on executive resource and the changing role of the board in leadership assessment, executive talent succession planning: reengineered for the twenty-first century. As a result of the "activist" institutional investor, succession and executive development are now in the top five priorities for many chief executive officers. Just what is driving this change, and why do we need to reengineer our replacement planning, strategic staffing, talent development and performance management processes into one integrated process? Shares resulted 
from over five years of research and application regarding succession planning, strategic staffing, and competencies including a benchmarking with many of North America's "better practice" companies. The work discussed the changing role of the board in leadership assessment and chief executive officer selection; why the business context is the starting point for effective talent pool management and considers options for executive resourcing process design and discussed why most of the current approaches to competencies and $360^{\circ}$ assessment fail to recognize how leadership and effective leader behaviours change by work level. They found that there is need to clarify for line managers potential. Rothwell [9] conducted research aimed to review the executive management positions within the six institutional health boards along with the Newfoundland and Labrador Health Boards Association (NLHBA), in order to outline the potential departures of executive managers due to normal retirement as well as early retirement. In completing this study all forty-one executive managers received a survey requesting particular information with respect to years of service in the health sector and the length of time in the incumbents' current position. Pension records for all but one of the executive managers were reviewed in aggregate, unidentifiable format. The findings indicated that fifty-four point five (54.5) per cent of respondents have been in their current position for greater than five years while one hundred per cent of respondents had greater than five years of experience in the health system. In reviewing the normal retirement age of each of the executive managers (this is defined as normal age of retirement which the incumbent will not have any reduction in his/her pension), approximately twenty-two per cent of executive managers will retire within the next ten years. In considering those who have the option to retire early with a reduced pension, this number increases to fifty-four (54) per cent of managers who will be eligible to retire within the next ten years of which twenty-eight per cent can retire within the coming three years. Vikstrom \& Wennberg [21] wrote on succession in private firms as an entrepreneurial process. They argue that succession in private firms is an entrepreneurial process. In considering firm succession as the acts of entrepreneurial exit and entry, their work adds to work that sought to integrate entrepreneurship and family business research. They provided a comprehensive literature review of succession research over the past 35 years and identified seven thematically clusters within which succession can be understood as a distinct part of the entrepreneurial process, and three areas of particular interest for future research seeking to advance the literatures on entrepreneurship, family firms, and governance in private firms. The paper explores theoretical, conceptual, and methodological ways of integrating these findings into the research on entrepreneurship and family business. Vikström and Westerberg [21] did a study on succession in small family firms. Their study found that leadership succession factors is associated to attitudes, norms and perceived behavioral control. Leading actors in a small family firm can be related to how well the succession process works and to the firm's post-transition performance.

\section{Research method}

For this study, the survey method was adopted. The ex-post facto method which involved the use of secondary data from the internet, journals and articles 
was employed. A cross-sectional design was adopted. The study population refers to the entire number of employees in the five selected SMEs in Abeokuta, Ogun state based on the registration of the SMEs with C.A.C. The five (5) companies include: Day Water Man School, ACE Supermarket, Abimbola Agro Allied Ltd, Aderupopo Farms Ltd and $\mathrm{M}$ and $\mathrm{M}$ enterprises Ltd. For this study the sample size is determined using Yamane formula. This formula is concerned with applying a normal approximation with a confidence level of $95 \%$ and a limit of tolerance level (error level) of $5 \%$.

Therefore, the sample size is determined by

$$
\begin{gathered}
\mathrm{n}=\left[\frac{N}{1+N e^{2}}\right] \\
\text { where } \mathrm{n}=\text { the sample size } \\
\mathrm{N}=\text { population } \\
\mathrm{e}=\text { the limit of tolerance } \\
\text { Therefore, } \mathrm{n}=\frac{152}{1+152(0.05)}{ }^{2} \\
=\frac{152}{1+152(0.0025)} \\
=\frac{152}{1+0.38} \\
=\frac{152}{1.38} \\
=110.14
\end{gathered}
$$

A sample of one hundred and ten (110) employees out of the one hundred and fifty two (152) employee population of the selected SMEs in Abeokuta, Ogun State. For this study, the simple random sampling technique was adopted. The questionnaire was divided in two broad categories. The first category is made up of personal data of respondents. Their; sex, age group, educational qualification, position occupied in firm and years of work experience. The second category is the body of the questionnaire that includes all questions relevant to this research. It comprises of both negative and positive questions structured on the basis of the six constructs of this research study, i.e. Outsourcing strategies and Organizational performance respectively. The likert-scale was used to measure opinions, where for positive questions (Strongly Agree $=5$, Agree $=4$, Undecided = 3, Disagree $=2$, Strongly Disagree = 1), and for negative questions (Strongly Agree = 1, Agree = 2, Undecided $=3$, Disagree $=4$, Strongly Disagree $=5$ ). Finally, Section 4 in the second category of the research instrument is made up of two related open -ended questions. Towards this end, the test re-test reliability approach was adopted for the convenience of the researcher. Reliability was ensued by Cronbach's Alpha of 0.932. The detail of the reliability statistics table is shown below.

Reliability Statistics

\begin{tabular}{|c|c|}
\hline Cronbach's Alpha & N of Items \\
\hline .932 & 42 \\
\hline
\end{tabular}

Source: Field Survey, 2020 
Cronbach's Alpha coefficient is .932 for the 42 items that were analyzed together. It therefore indicates that the research instrument used for this study is highly reliable as it is more than the generally accepted reliability score of 0.7 . The data was analyzed using manual and electronic based methods through the data preparation grid and statistical package for the social sciences, (SPSS). The utilization of structured grids allows specific responses to be located with relative ease and facilitate the identification of emerging patterns. Also descriptive, statistical and content analyses techniques was used in the analysis of the data collected. The study used the descriptive analysis to achieve the mean, frequency distribution and percentage results of the research work. The study made use of statistical tools which include: analysis of variance (ANOVA), correlation efficient and regression analysis in testing hypotheses where applicable.

Table 2

Distribution of Respondents and Response Rate

\begin{tabular}{|l|c|c|}
\hline $\begin{array}{l}\text { Respondents } \\
\text { Occupation }\end{array}$ & $\begin{array}{c}\text { Questionnaire administered } \\
\text { (sampled) }\end{array}$ & $\begin{array}{c}\text { Percentage of total response } \\
\text { (\%) }\end{array}$ \\
\hline Top Level & 10 & 52.7 \\
\hline Middle Level & 48 & 36.3 \\
\hline Level Lower & 33 & 11.0 \\
\hline Total & 91 & 100.0 \\
\hline Gender/Category & $\begin{array}{c}\text { Questionnaire administered } \\
\text { (sampled) }\end{array}$ & $\begin{array}{c}\text { Percentage of total response } \\
\text { (\%) }\end{array}$ \\
\hline Male & 40 & 44.0 \\
\hline Female & 51 & 56.0 \\
\hline No of Returned & 91 & 82.73 \\
\hline No of Not Returned & 19 & 17.27 \\
\hline $\begin{array}{l}\text { Total no of } \\
\text { Questionnaires }\end{array}$ & 110 & 100 \\
\hline
\end{tabular}

Source: Field Survey, 2020

\section{Data analysis and Hypothesis Testing}

The Descriptive statistics of Management Succession and Entrepreneurship Business Sustenance

\begin{tabular}{|l|c|c|}
\hline Responses & Total (N) & Mean \\
\cline { 1 - 2 } WORKERS EDUCATION AND SURVIVAL OF ENTREPRENUEUR & 91 & 4.56 \\
\hline Your company get involve in organizational learning and development & 91 & 3.68 \\
\hline Human resources training in organizations is based on merit & 91 & 3.89 \\
\hline $\begin{array}{l}\text { Workers education has contributed to the continuity of business in our } \\
\text { company }\end{array}$ & 91 & 3.99 \\
\hline $\begin{array}{l}\text { Your company engages in workers education (e.g. seminars, workshop, } \\
\text { development etc.) }\end{array}$ & 91 & 3.79 \\
\hline Workers education contribute to the growth of your company &
\end{tabular}


End of the table 3

\begin{tabular}{|l|c|c|}
\hline HR PLANNING AND FAMILY BUSNIESS CONTINUITY & Total (N) & Mean \\
\hline $\begin{array}{l}\text { Succession planning strategies adopted by the management enhances } \\
\text { business survival }\end{array}$ & 91 & 3.68 \\
\hline $\begin{array}{l}\text { Human Resources succession planning as an important factor of } \\
\text { organizational survival }\end{array}$ & 91 & 3.78 \\
\hline Effective Succession Planning Contribute to Organization Performance & 91 & 3.56 \\
\hline $\begin{array}{l}\text { Human Resources Succession Planning contribute to the Growth of } \\
\text { organization }\end{array}$ & 91 & 3.78 \\
\hline Succession Planning increases the availability of experienced workers & 91 & 3.75 \\
\hline Organizations conduct Human Resources Succession Planning & 91 & 3.58 \\
\hline
\end{tabular}

Source: Field Survey 2020

\section{Test of Hypotheses and Discussion of Results}

Hypothesis 1:

$\mathbf{H}_{\mathbf{0}}$ : There is no effect of HR planning on family business continuity

$\mathbf{H}_{\text {I }}$ : There is effect of HR planning on family business continuity

Model Summary

\begin{tabular}{|c|c|c|c|c|c|}
\hline \multirow{2}{*}{ Model } & \multicolumn{5}{|c|}{ Change Statistics } \\
\cline { 2 - 6 } & $\begin{array}{c}\text { RSquare } \\
\text { Change }\end{array}$ & F Change & df1 & df2 & Sig. F Change \\
\hline 1 & $.458^{\text {a }}$ & 75.314 & 1 & 89 & .000 \\
\hline
\end{tabular}

a. Predictors: (Constant), HR succession planning

Source: Field Survey, 2020

Table 5

ANOVA $^{b}$

\begin{tabular}{|c|c|c|c|c|c|c|}
\hline \multicolumn{2}{|c|}{ Model } & $\begin{array}{c}\text { Sum of } \\
\text { Squares }\end{array}$ & Df & Mean Square & F & Sig. \\
\hline \multirow{3}{*}{1} & Regression & 8.656 & 1 & 8.656 & 75.314 & $.000^{\mathrm{a}}$ \\
\cline { 2 - 8 } & Residual & 10.229 & 89 & .115 & & \\
\cline { 2 - 8 } & Total & 18.884 & 90 & & & \\
\hline
\end{tabular}

a. Predictors: (Constant), HR succession planning

b. Dependent Variable: Business Continuity

Source: Field Survey, 2020

\section{Interpretation of Results}

The results from the model summary table above revealed that the extent to which the variance in business continuity can be explained by human resources succession planning is $36.3 \%$ i.e ( $\mathrm{R}$ square $=0.458$ ). The ANOVA table shows the Fcal 75.314 at 0.0001 significance level. Human resources succession planning significantly assists SMEs to increase business continuity. 


\section{Coefficients $^{\mathrm{a}}$}

\begin{tabular}{|c|c|c|c|c|c|c|}
\hline \multirow{2}{*}{ Model } & \multicolumn{2}{|c|}{$\begin{array}{c}\text { Unstandardized } \\
\text { Coefficients }\end{array}$} & $\begin{array}{c}\text { Standardized } \\
\text { Coefficients }\end{array}$ & \multirow{2}{*}{ T } & \multirow{2}{*}{ Sig. } \\
\cline { 3 - 5 } \multicolumn{2}{|c|}{} & B & Std. Error & Beta & & \\
\hline \multirow{2}{*}{1} & (Constant) & 1.895 & .266 & & 7.129 & .000 \\
\cline { 2 - 5 } & $\begin{array}{c}\text { HR succession } \\
\text { planning }\end{array}$ & .565 & .065 & .677 & 8.678 & .000 \\
\hline
\end{tabular}

a. Dependent Variable: Business Continuity

Source: Field Survey, 2020

The coefficient table above shows the simple model that expresses how human resource succession planning affects SMEs business continuity. The model is shown mathematically as follows;

$\mathrm{Y}=\mathrm{a}+\mathrm{bx}$ where $\mathrm{y}$ is business continuity and $\mathrm{x}$ is human resources succession planning, $a$ is a constant factor and $b$ is the value of coefficient. From this table therefore, Business continuity $=1.895+0.565 \mathrm{HR}$ succession planning. This means that for every $100 \%$ change in business continuity, human resources succession planning contributed $56.5 \%$

The significance level below 0.01 implies a statistical confidence of above 99\%. This implies that Human resources succession planning affect SMEs Business continuity. Thus, the decision would be to reject the null hypothesis (H0), and accept the alternative hypothesis (H1).

\section{Hypothesis 2}

$\mathbf{H}_{\mathbf{0}}$ : There is no effect of worker's education on survival of entrepreneur

$\mathbf{H}_{\mathbf{I}}$ : There is effect of worker's education on survival of entrepreneur

Model Summary

\begin{tabular}{|c|c|c|c|c|c|}
\hline \multirow{2}{*}{ Model } & \multicolumn{5}{|c|}{ Change Statistics } \\
\cline { 2 - 6 } & $\begin{array}{c}\text { R Square } \\
\text { Change }\end{array}$ & F Change & df1 & df2 & Sig. F Change \\
\hline 1 & $.100^{\mathrm{a}}$ & 9.871 & 1 & 89 & .002 \\
\hline
\end{tabular}

a. Predictors: (Constant), workers education

Source: Field Survey, 2020

Table 8

ANOVA ${ }^{\mathbf{b}}$

\begin{tabular}{|c|c|c|c|c|c|c|}
\hline \multicolumn{2}{|c|}{ Model } & $\begin{array}{c}\text { Sum of } \\
\text { Squares }\end{array}$ & Df & Mean Square & F & Sig. \\
\hline \multirow{3}{*}{1} & Regression & 2.825 & 1 & 2.825 & 9.871 & $.002^{\text {a }}$ \\
\cline { 2 - 8 } & Residual & 25.473 & 89 & .286 & & \\
\cline { 2 - 8 } & Total & 28.298 & 90 & & & \\
\hline
\end{tabular}

a. Predictors: (Constant), workers education

b. Dependent Variable: Business Survival

Source: Field Survey, 2020 


\section{Interpretation of Results}

The results from the model summary table above revealed that the extent to which the variance in business survival can be explained by workers education is $10.0 \%$ i.e. $(\mathrm{R}$ square $=0.100$ ). The ANOVA table shows the Fcal 9.871 at 0.0001 significance level. Workers education significantly assists SMEs to increase business survival.

Table 9

Coefficients

\begin{tabular}{|c|c|c|c|c|c|c|}
\hline & \multirow{2}{*}{ Model } & \multicolumn{2}{|c|}{ Unstandardized Coefficients } & $\begin{array}{c}\text { Standardized } \\
\text { Coefficients }\end{array}$ & \multirow[t]{2}{*}{$\mathrm{t}$} & \multirow[t]{2}{*}{ Sig. } \\
\hline & & B & Std. Error & Beta & & \\
\hline \multirow[b]{2}{*}{1} & (Constant) & 3.127 & .309 & & 10.131 & .000 \\
\hline & $\begin{array}{l}\text { workers } \\
\text { education }\end{array}$ & .227 & .072 & .316 & 3.142 & .002 \\
\hline
\end{tabular}

a. Dependent Variable: Business Survival

Source: Field Survey, 2020

The coefficient table above shows the simple model that expresses how workers education affects SMEs business survival. The model is shown mathematically as follows;

$\mathrm{Y}=\mathrm{a}+\mathrm{bx}$ where $\mathrm{y}$ is business survival and $\mathrm{x}$ is workers education, $\mathrm{a}$ is a constant factor and $b$ is the value of coefficient. From this table therefore, Business survival $=3.127+0.227$ Workers education. This means that for every $100 \%$ change in business survival, workers education contributed $22.7 \%$

\section{Empirical Findings}

The findings of this study demonstrated a meaningful relationship between organizational requirements such as managers' commitment, organizational culture, organizational readiness, and managers' competencies with the implementation of succession planning. The finding of this study also reveals that human resources succession planning has enhanced positively. Also, the finding shows that human resources training have significantly increase business growth. Workers education has also helped the business survival of SMEs to a certain extent.

\section{Conclusion}

Succession planning has become one of the most significant human resource management responsibilities within today's organizations. The best way to address these challenges is to retain and develop potential employees. This means that organizations need to work to develop awareness on succession planning. This paper concludes that the management of SMEs in Nigeria must endeavor to make their institutions continuously significant and competitive by motivating employees towards increased effectiveness and efficiency. Also, there must be appropriate 
management of talented employees to reduce employee turnover rate. Effective human resource and succession planning will no doubt transform SMEs in Nigeria. It will affect the functioning and the level of readiness to confront future difficulties. To reposition SMEs for effective performance organizations must institute efficient human resource and succession planning to assemble teams of internal talents aimed at improving management continuity, ethics and philosophy. This will ease the growth of talent reserve and be crucial in attracting and retaining superior talent to assist in the current and potential organization development.

\section{Recommen dations}

1. The study recommends that SMEs should have succession laws to ensure smooth transition as well as the role of the successors.

2. The study also recommends that organizations should have effective business practices since it has a positive influence on the succession planning.

3. The organizations should have strategic practices which will assist in manpower planning and human relation succession planning.

4. The study recommends that organizational succession planning should be at regular interval as this will enable workers to know its importance.

5. Finally, the study recommends that business successors should be appoint based on merit so that the right and experience successors manage the business.

Suggestions for further studies

The findings of this study did not exhaust all technicalities of management succession planning. The study explored only challenges which faced management succession planning of SMEs in Abeokuta Ogun State which were limited to five SMEs. Therefore, other researchers should conduct study in other companies including those located in other regions. Also, further study should aim to explore advantages which the organizations reap from succession planning.

\section{REFERENCES}

[1] Armstrong M.A Handbook of Human Resource Management Practice. Kogan Page Publishers. 2015;9:1-440.

[2] Gilbert L.J., Judith B. Workforce Planning Not a Common Practice, IPMA-HR Study Finds. Sage Journals. 2004;33(4):379-388. DOI: https://doi.org/10.1177/009102600403300403

[3] Kouzes J.M., Posner B.Z. The Leadership Challenges ( $3^{\text {rd }}$ Ed.). San Francisco: Wiley; 2002.

[4] Sambrook S., Sambrook S.A. Exploring Succession Planning in Small, Growing Firms. Journal of Small Business and Enterprise Development. 2005;12(4):579-594. DOI: https://doi.org/10.1108/14626000510628243

[5] Warren G.B. On Becoming a Leader. N.Y.: Addison-Wesley Pub; 1989.

[6] Narayan R. Human Resource Accounting: A New Paradigm in the Era of Globalization. Asian Journal of Management Research. 2010;1:237-244.

[7] Douglas T.H. Career in and out of Organizations. California: Sage Publications; 2002. DOI: http://dx.doi.org/10.4135/9781452231174

[8] Diamond A. Finding Success Through Succession Planning. Sec. Manage. 2006;50(2):36-39.

[9] Rothwell W.J. White Paper: 10 Key Steps to Effective Succession Planning. URL: https://www.hrgrapevine.com/content/article/2014-11-06-white-paper-10-key-steps-to-effectivesuccession-planning. Accessed: 24.05.2021.

[10] McBey K., Belcourt M. Strategic Human Resource Planning. Toronto: Nelson Education Limited; 2015.

[11] Noe A., Houston G., Hollenbeck R., Gerhart., Wright M. Human Resource Management Gaining a competitive Advantage 3rd Edition. Boston: McGraw-Hill Companies Inc; 2000. 
[12] Byham W.C., Smith A.B., Paese M.J. Grow Your Own Leaders: How to Identify, Develop and Retain Leadership Talent. New York: Prentice Hall; 2002.

[13] Bill G. Authentic Leadership: Rediscovering the Secrets to Creating Lasting Value. San Francisco: Jossey-Bass; 2004.

[14] Rothwell W.J. Putting Success into Your Succession Planning. Journal of Business Strategy. 2002;23(3):32-37. DOI: https://doi.org/10.1108/eb040249

[15] Rothwel W.J. Effective Succession Planning: Ensuring Leadership Continuity and Building Talent from Within (2nd Ed.). New York: AMACOM; 2010.

[16] Hills A. Succession Planning - or Smart Talent Management? Industrial and Commercial Training. 2009;41(1):3-8. DOI: https://doi.org/10.1108/00197850910927697

[17] Bernthal P.R., Wellins R.S. Leadership Forecast 2005-2006: Best Practices for Tomorrow's Global Leaders. Pittsburgh, PA: Development Dimensions International; 2006.

[18] Gardner J.W. On Leadership. New York: The Free Press; 1990.

[19] Leinsdorf B. Boomers' Retirement May Create Talent Squeeze. The Chronicle of Higher Education. URL: https://www.chronicle.com/article/boomers-retirement-may-create-talentsqueeze/. Accessed: 24.05.2021.

[20] William C.L., James C.C. Beyond Entrepreneurship: Turning Your Business into an Enduring Great Company. Englewood Cliffs: Prentice Hall; 1992.

[21] Vikström A., Westerberg M. Success with Succession: An Empirical Study of Small Swedish Family Firms. International Journal of Entrepreneurship and Small Business. 2010;11(3):1-19. DOI: 10.1504/IJESB.2010.035816

[22] Byham W.C., Bernthal P.R. The Case for Internal Promotions [White Paper]. Bridgeville, PA: Development Dimensions International; 2006.

[23] Ip B., Jacobs G. Business Succession Planning: a Review of the Evidence. Journal of Small Business and Enterprise Development. 2006;13(3):326-350. DOI: 10.1108/ 14626000610680235

[24] Blaskey M.S. Succession Planning with a Business Living Will. Journal of Accountancy. 2002;193(5):22-23.

[25] Fulmer R. Keys to Best Practice in Succession Management. URL: www.humanresourcemagazine.com. Accessed: 31.10.2007.

[26] Maxwell J.C. Leadership 101: What Every Leader Needs to Know. Nashville, TN: Thomas Nelson; 2012.

[27] Wellins R.S., Smith A.B., Paese M.J., Erker S. Nine Best Practices for Effective Talent Management [White Paper]. Bridgeville, PA: Development Dimensions International; 2012.

[28] Zeiss T. Get 'Em While They're Hot: How to Attract, Develop and Retain Peak Performers in the Coming Labor Shortage. Nashville, TN: Nelson Business; 2005.

[29] Farashah D.A., Nasehifar V., Karahrudi S.A. Succession Planning and its Effects on Employee Career Attitudes: Study of Iranian Governmental Organizations. African Journal of Business Management. 2011;5(9):3605-3613.

[30] Barden D.M. The Internal-Candidate Syndrome: All the Parties Involved in an Open, National Search are Vulnerable when the Applicant Pool Includes an Inside. The Chronicle of Higher Education. URL: https://www.chronicle.com/. Accessed: 07.04.2020.

[31] Barden D.M. Your Next Few Leaders: The Time has Come for Colleges and Universities to Get Serious About Succession Planning. The Chronicle of Higher Education. URL: https://www.chronicle.com/. Accessed: 08.05.2021.

[32] U.S. Equal Employment Opportunity Commission (U.S. EEOC 2007). URL: https://www.eeoc.gov/. Accessed: 23.04.2021.

[33] Wennberg K., Nordqvist M., Bau M., Hellerstedt K. Succession in Private Firms as an Entrepreneurial Process - A Review and Suggestions of New Research avenues. Ratio Working Papers 157. Stockholm: The Ratio Institute; 2010.

[34] Hattingh B. Put Success into Succession Planning. URL: https://cycan.co.za/. Accessed: 15.04.2021.

[35] Kirby C. Survey of "Grow Your Own" Leadership Opportunities in Illinois Community Colleges. In Update. 2007;1(16). URL: http://occrl.ed.uiuc.edu. Accessed: 15.04.2021. 
[36] Bowen W. The Successful Succession: How to Manage the Process of Picking a President. The Chronicle of Higher Education. URL: www.chronicle.com. Accessed: 07.04.2021.

\title{
Information about the authors:
}

Solomon A. Kowo - PhD, Lecturer of the Department of Business and Entrepreneurship, Kwara State University (Nigeria) (ORCID ID: 0000-0002-0504-2248) (e-mail: kowosolomon@gmail.com).

Olalekan O. Akinrinola - PhD, Senior Lecturer of the Department of Accounting and Finance, Caleb University Lagos (Nigeria) (e-mail: oakinrinola@yahoo.com).

Olufemi A. Akinbola - PhD, Lecturer of the Department of Business Administration, Federal University of Agriculture, Abeokuta, (Nigeria) (ORCID ID: 0000-0001-7916-4136) (e-mail: femiakinbola@gmail.com).

\section{Замещение управленческих должностей и поддержание предпринимательской деятельности}

\author{
С.А. Ково $1 \bowtie$, О.О. Акинринола², О.А. Акинбола ${ }^{3}$ \\ ${ }^{1}$ Государственный университет Квара, \\ Нигерия, итат Квара, Илорин, РМВ - 1530 \\ ${ }^{2}$ Университет Калеб, \\ Нигерия, штат Лагос, Имота, РМВ - 1 \\ ${ }^{3}$ Федеральный сельскохозяйственный университет, \\ Нигерия, штат Огун, Абеокута, д. Алабата, РМВ - 2240 \\ $\triangle$ kowosolomon@gmail.com
}

\begin{abstract}
Аннотация. Планирование преемственности вызывает значительный интерес среди исследователей. Отчеты об исследованиях указывают на недостаток кадрового планирования в управлении МСП, особенно в развивающихся странах, таких как Нигерия, и это является основным ограничением для эффективного управления МСП. Планирование замещения кадров имеет фундаментальное значение для стабильной работы, устойчивости и конкурентных преимуществ МСП. Целью исследования было изучить влияние планирования/прогнозирования кадровых ресурсов на непрерывность семейного бизнеса, а также изучить влияние образования работников на сохранение деятельности предпринимателя. В рамках исследования были анкетированы 110 сотрудников пяти выбранных малых и средних предприятий в штате Абеокута Огун, Нигерия, чтобы получить первичные данные, которые позволили соответствующим образом обработать и проверить соответствующие исследовательские вопросы и гипотезы. В исследовании используется дисперсионный анализ (ANOVA), эффективная корреляция и регрессионный анализ. Формула Ямана использовалась для определения размера выборки. Для проверки точности выводов проводилось повторное тестирование. Надежность была обеспечена критерием оценки альфа Кронбаха 0,932. Данные были проанализированы с использованием ручных и электронных методов с использованием сетки подготовки данных и статистического пакета для социальных наук (SPSS). Исследование показало, что планирование кадровой преемственности значительно помогает малым и средним предприятиям повысить непрерывность работы предприятия, а образование сотрудников значительно помогает предприятиям выживать. В исследовании рекомендуется, чтобы планирование преемственности в организации проводилось через регулярные промежутки времени, поскольку это позволит работникам понять его важность, а также следует назначать преемников на основе заслуг, чтобы правопреемники и опытные преемники могли эффективнее управлять бизнесом.
\end{abstract}

Ключевые слова: Замещение управленческих должностей, поддержка бизнеса, образование работников, планирование персонала, непрерывность бизнеса 
Заявление о конфликте интересов: Авторы заявляют об отсутствии конфликта интересов.

\section{История статьи:}

Поступила в редакцию: 01.05.2021. Принята к публикации: 25.05.2021.

\section{Для цитирования:}

Ково С.А., Акинринола О.О., Акинбола О.А. Замещение управленческих должностей и поддержание предпринимательской деятельности // Вестник Российского университета дружбы народов. Серия: Государственное и муниципальное управление. 2021. Т. 8. № 3. С. 256-276. DOI: $10.22363 / 2312-8313-2021-8-3-256-276$

\section{Информация об авторах:}

Соломон Акповироро Ково - $\mathrm{PhD}$, преподаватель кафедры бизнеса и предпринимательства Государственного университета Квара (Нигерия) (ORCID ID: 0000-0002-0504-2248) (e-mail: kowosolomon@gmail.com).

Олалекан Оладипо Акинринола - $\mathrm{PhD}$, старший преподаватель кафедры бухгалтерского учета и финансов Университета Калеба, Лагос (Нигерия) (e-mail: oakinrinola@yahoo.com).

Олуфеми Амос Акинбола - PhD, преподаватель кафедры делового администрирования Федерального сельскохозяйственного университета (Нигерия) (ORCID ID: 0000-0001-7916-4136) (e-mail: femiakinbola@gmail.com). 